\title{
Evidence for Sodium-dependent Active Urea Secretion in the Deepest Subsegment of the Rat Inner Medullary Collecting Duct
}

\author{
Akihiko Kato and Jeff M. Sands \\ Renal Division, Department of Medicine, Emory University School of Medicine, Atlanta, Georgia 30322
}

\begin{abstract}
Active reabsorption of urea appears in the initial IMCD $\left(\mathrm{IMCD}_{1}\right)$ of rats fed a low-protein diet. To determine whether active urea transport also occurs in the deepest IMCD subsegment, the $\mathrm{IMCD}_{3}$, we isolated IMCDs from the base $\left(I M C D_{1}\right)$, middle $\left(I M C D_{2}\right)$, and tip $\left(\operatorname{IMCD}_{3}\right)$ regions of the inner medulla from rats fed a normal protein diet and water ad libitum. IMCDs were perfused with identical perfusate and bath solutions. A significant rate of net urea secretion was present only in $\mathrm{IMCD}_{3} \mathrm{~s}$. Replacing perfusate $\mathrm{Na}^{+}$with $\mathrm{NMDG}^{+}$reversibly inhibited net urea secretion but replacing bath $\mathrm{Na}^{+}$with $\mathrm{NMDG}^{+}$or perfusate $\mathrm{Cl}^{-}$with gluconate ${ }^{-}$had no effect. Net urea secretion was significantly inhibited by: (a) $250 \mu \mathrm{M}$ phloretin (perfusate); (b) $100 \mathrm{nM}$ triamterene (perfusate); (c) $1 \mathrm{mM}$ ouabain (bath); and $(d)$ cooling the tubule to $23^{\circ} \mathrm{C}$. Net urea secretion was significantly stimulated by $10 \mathrm{nM}$ vasopressin (bath). Next, we perfused $\mathrm{IMCD}_{3}$ s from water diuretic rats (given food ad libitum) and found a significant, fivefold increase in net urea secretion. In summary, we identified a secondary active, secretory urea transport process in $\mathrm{IMCD}_{3} \mathrm{~S}$ of normal rats which is upregulated in water diuretic rats. This new urea transporter may be a sodiumurea antiporter. (J. Clin. Invest. 1998. 101:423-428.) Key words: urea • sodium • IMCD • vasopressin • urine-concentrating mechanism
\end{abstract}

\section{Introduction}

Active urea transport pathways are present in the kidneys of several mammalian and nonmammalian species. For example, active urea reabsorption occurs in elasmobranch fishes $(1,2)$ and active urea secretion is present in the frog kidney $(3,4)$. In mammalian kidney, the presence of active urea secretion in rabbit proximal straight tubules is controversial since one

Portions of this work were presented at the 30th annual meeting of the American Society of Nephrology, 2-5 November 1997 in San Antonio, TX and have appeared in abstract form (1997. J. Am. Soc. Nephrol. 8:19A-20A.).

Address correspondence to Jeff M. Sands, Emory University School of Medicine, Renal Division, WMRB Room 338, 1639 Pierce Drive, NE, Atlanta, GA 30322. Phone: 404-727-2435; FAX: 404-7273425; E-mail: jsands@emory.edu

Received for publication 5 August 1997 and accepted in revised form 17 November 1997.

J. Clin. Invest.

(C) The American Society for Clinical Investigation, Inc. 0021-9738/98/01/0423/06 \$2.00

Volume 101, Number 2, January 1998, 423-428

http://www.jci.org study demonstrated a small net urea flux (5), while a second study did not (6). Based upon results from clearance studies, active urea secretion is also thought to be present in $\operatorname{dog}(7,8)$ and human (9) kidney. We showed that urea transport is physiologically regulated because urea is actively reabsorbed by a secondary active, sodium-coupled cotransport mechanism in the initial inner medullary collecting duct $\left(\mathrm{IMCD}_{1}\right)^{1}$ of rats fed a low-protein diet, but not in the middle third of the IMCD, the $\mathrm{IMCD}_{2}(10)$ of rats fed a low-protein diet (11) nor in the $\mathrm{IMCD}_{1}$ or IMCD $\mathrm{IM}_{2}$ of rats fed a normal protein diet (11-13).

The $\mathrm{IMCD}_{3}$ is the deepest third of the IMCD and is located in the papillary tip (10). It consists entirely of a unique cell type, the IMCD cell (14). This short portion is difficult to microdissect due to the close proximity of many branches and there are no isolated perfused tubule studies addressing whether active urea transport exists in this segment. In this study, we measured net urea flux in each of the three IMCD subsegments using the isolated perfused tubule technique. After demonstrating that urea was actively secreted only in $\mathrm{IMCD}_{3} \mathrm{~s}$, we next examined the mechanism for this active urea transport.

\section{Methods}

Tissue preparation. All animal protocols were approved by the Emory University Institutional Animal Care and Use Committee. Tubules were obtained from pathogen-free male Sprague-Dawley rats (National Cancer Institute, Frederick, MD). The rats were kept in filter-top cages with autoclaved bedding and received free access to water and a normal protein diet (NIH-31; Ziegler Brothers, Gardner, PA) unless otherwise indicated below. $20 \mathrm{~min}$ before each experiment, furosemide (5 mg intraperitoneally [IP]) was administered (15). The kidneys were placed into chilled $\left(17^{\circ} \mathrm{C}\right)$, isotonic, dissecting solution to isolate initial $\left(\mathrm{IMCD}_{1}\right)$ or terminal $\left(\mathrm{IMCD}_{2}\right.$ or $\left.\mathrm{IMCD}_{3}\right)$ IMCD subsegments $(10,14)$ as described $(15,16)$.

To alter the rat's hydration status, the following protocols were used: (a) Untreated (control). Rats were given food and water ad libitum for 3-5 d; $(b)$ water diuresis. Rats were fed $10 \%$ glucose in water without additional food for 3-5 d. We combined the results from rats undergoing water diuresis for 3-5 d since there were no differences in the data obtained from these rats; $(c)$ water diuresis + food. Rats were fed $10 \%$ glucose in water and given free access to food for 3-5 d. We combined the results from rats undergoing water diuresis for 3-5 d since there were no differences in the data obtained from these rats; (d) water deprivation. Rats were given free access to food but given no water for $2-3 \mathrm{~d}$. We combined the results from rats which were water restricted for 2-3 d since there were no differences in the data obtained from these rats.

The dissecting solution was gassed with $95 \% \mathrm{O}_{2}$ and $5 \% \mathrm{CO}_{2}$ and contained: $118 \mathrm{mM} \mathrm{NaCl} ; 25 \mathrm{mM} \mathrm{NaHCO}{ }_{3} ; 2 \mathrm{mM} \mathrm{CaCl}_{2} ; 2.5 \mathrm{mM}$ $\mathrm{K}_{2} \mathrm{HPO}_{4} ; 1.2 \mathrm{mM} \mathrm{MgSO}$; $5.5 \mathrm{mM}$ glucose; and $4 \mathrm{mM}$ creatinine. Tubules were transferred into a bath which was continuously exchanged and bubbled with $95 \% \mathrm{O}_{2} / 5 \% \mathrm{CO}_{2}$ gas and perfused using standard

1. Abbreviations used in this paper: AVP, arginine vasopressin; IMCD, inner medullary collecting duct. 
techniques $(11-13,15,16)$. The osmolality of all solutions was measured by vapor pressure osmometry (model 5500; Wescor, Logan, UT).

Urea measurement. The urea concentration in perfusate, bath, and collected fluid was measured using a continuous-flow ultramicrofluorometer as described $(11-13,15,16)$. Urea flux $\left(\mathrm{J}_{\text {urea }}\right)$ was calculated as: $J_{\text {urea }}=C_{o} V_{o}-C_{1} V_{1}$, where $C_{o}$ is the urea concentration in the perfusate, $C_{1}$ is the urea concentration in the collected fluid, $V_{o}$ is the perfusion rate per unit length of tubule, and $V_{1}$ is the collection rate per unit length of tubule. Based upon this formula, a positive value for $\mathrm{J}_{\text {urea }}$ indicates urea reabsorption while a negative value indicates urea secretion.

To study net urea transport, tubules were perfused with identical perfusate and bath solutions whose composition were identical to the dissection solution described above except that $3 \mathrm{mM}$ urea was added to all solutions (11-13). To calculate $\mathrm{J}_{\text {urea }}, \mathrm{V}_{\mathrm{o}}$ is assumed to be equal to $\mathrm{V}_{1}$, because there is no osmotic gradient across the tubule and hence, no driving force for water reabsorption. We showed that the measured volume flux is 0 under these experimental conditions (11).

Effect of vasopressin or inhibitors on net urea transport. The urea concentration of three to four collections was measured, after which: (a) $10 \mathrm{nM}$ arginine vasopressin (AVP; Sigma Chemical Co., St. Louis, MO) was added to the bath (13); (b) $250 \mu \mathrm{M}$ phloretin (Sigma Chemical Co.) was added to the perfusate $(11,13) ;(c) 1 \mathrm{mM}$ ouabain (Sigma Chemical Co.) was added to the bath $(13,17) ;(d) 100 \mathrm{nM}$ triamterene (Sigma Chemical Co.) was added to the perfusate (18); or (e) the tubule was cooled to $23^{\circ} \mathrm{C}(11)$; and three to four additional collections obtained. Next, the inhibitor was washed out and three to four additional collections obtained.

A 250-mM stock solution of phloretin was prepared in absolute ethanol and added to perfusate to achieve a final concentration of $250 \mu \mathrm{M}$ phloretin and $1 \%$ ethanol $(19,20)$. Control collections were obtained with $1 \%$ ethanol added to the perfusate $(11,13,19,20)$.

Effect of ion substitution on net urea transport. The urea concentration of three to four collections was measured. Next, $\mathrm{Na}^{+}$was removed from either the perfusate or bath and replaced by $N$-methylD-glucamine $^{+}$(in equimolar concentrations) and three to four collections were obtained. After the solution was changed to return $\mathrm{Na}^{+}$, three to four additional collections were obtained (13). In separate tubules, $\mathrm{Cl}^{-}$was removed from the perfusate and replaced with equimolar gluconate $^{-}$(21); three to four collections were obtained for each experimental condition.

Volume flux measurement. Creatinine concentration in perfusate, bath, and collected fluid was measured using a continuous-flow ultramicro-colorimeter and used to measure volume flux $(11,16)$.
Table I. Perfusate Flow Rate and Collected/Perfusate Urea Ratio

\begin{tabular}{lrccc}
\hline IMCD subsegment & Tubule length & Perfusate flow rate & $\begin{array}{c}\text { Collected/perfusate } \\
\text { urea ratio }\end{array}$ \\
\hline & $n$ & $m m$ & $n l / m i n$ & \\
$\mathrm{IMCD}_{1}$ & 5 & $0.52 \pm 0.06$ & $22.0 \pm 2.3$ & $0.99 \pm 0.004$ \\
$\mathrm{IMCD}_{2}$ & 5 & $0.67 \pm 0.12$ & $26.9 \pm 5.0$ & $0.99 \pm 0.01$ \\
$\mathrm{IMCD}_{3}$ & 14 & $0.62 \pm 0.04$ & $22.6 \pm 1.6$ & $1.11 \pm 0.02 *$ \\
& & & &
\end{tabular}

Data: mean \pm SE; $* P<0.01$ vs. 0 .

The perfusion rate $\left(\mathrm{V}_{\mathrm{o}}\right)$ was calculated as: $\mathrm{V}_{\mathrm{o}}=\mathrm{V}_{1}\left(\mathrm{Cr}_{1} / \mathrm{Cr}_{\mathrm{o}}\right)$, where $\mathrm{Cr}_{\mathrm{o}}$ is the creatinine concentration in the perfusate, $\mathrm{Cr}_{1}$ the creatinine concentration in the collected fluid, and $\mathrm{V}_{\mathrm{o}}$ and $\mathrm{V}_{1}$ are as defined above. Volume flux $\left(\mathrm{J}_{\mathrm{v}}\right)$ was calculated as: $\mathrm{J}_{\mathrm{v}}=\mathrm{V}_{\mathrm{o}}-\mathrm{V}_{1}$.

Statistics. All data are presented as mean \pm SE and $n=$ number of rats. Data from three to four collections were averaged to obtain a single value from each experimental phase in each tubule. To test for statistical significance between two groups, the Student's $t$ test was used. To test more than two groups, an ANOVA was used, followed by a multiple comparison, protected $t$ test (22) to determine which groups were significantly different. The criterion for statistical significance was $P<0.05$. Paired statistical analysis was used for the AVP, inhibitor, and ion substitution protocols since each tubule was used as its own control. Unpaired statistical analysis was used for the protocols comparing changes in hydration in vivo.

\section{Results}

Net urea flux. Basal net urea secretion $(-9.2 \pm 1.6 \mathrm{pmol} / \mathrm{mm}$ per min, $n=14, P<0.01$ vs. 0 ) is present in $\mathrm{IMCD}_{3}$ s from untreated rats (Fig. 1). In contrast, there was no significant net urea flux in $\mathrm{IMCD}_{1} \mathrm{~s}(0.1 \pm 0.5 \mathrm{pmol} / \mathrm{mm}$ per $\min , n=5)$ or $\mathrm{IMCD}_{2} \mathrm{~s}(1.0 \pm 0.5 \mathrm{pmol} / \mathrm{mm}$ per min, $n=5)$. Tubule lengths, perfusate flow rates, and collected/perfusate urea ratios are shown in Table I.

AVP (10 nM in the bath) increased net urea secretion in $\mathrm{IMCD}_{3} \mathrm{~s}$ from $-12.6 \pm 3.9 \mathrm{pmol} / \mathrm{mm}$ per min to $-30.7 \pm 6.4$ $\mathrm{pmol} / \mathrm{mm}$ per $\min (n=5, P<0.01$, Fig. 2 , dashed line $)$. How-

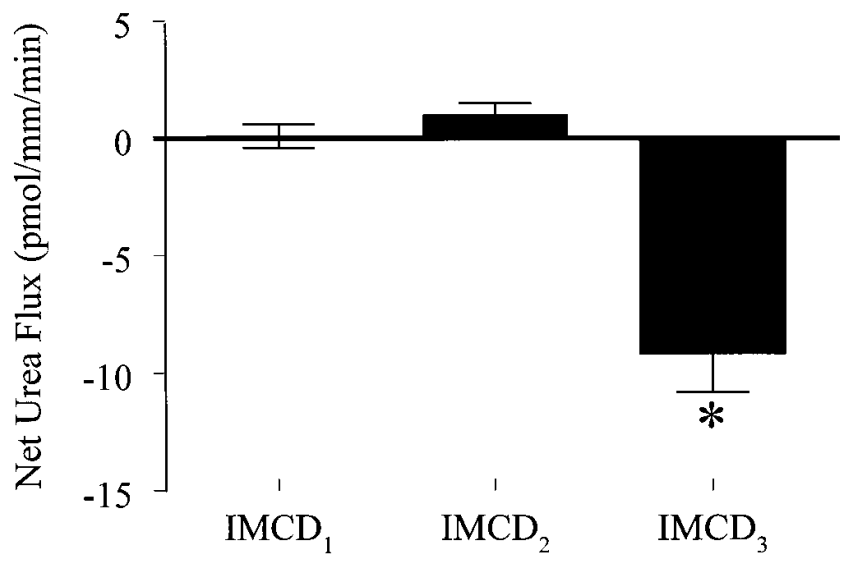

Figure 1. Net urea flux in IMCD subsegments. A significant rate of net urea secretion was present only in the $\mathrm{IMCD}_{3}$. Data: mean $\pm \mathrm{SE}$, $n=5$ in $\mathrm{IMCD}_{1}$ and $\mathrm{IMCD}_{2}, n=14$ in $\mathrm{IMCD}_{3}$. A negative net urea flux indicates net urea secretion. $* P<0.01$.

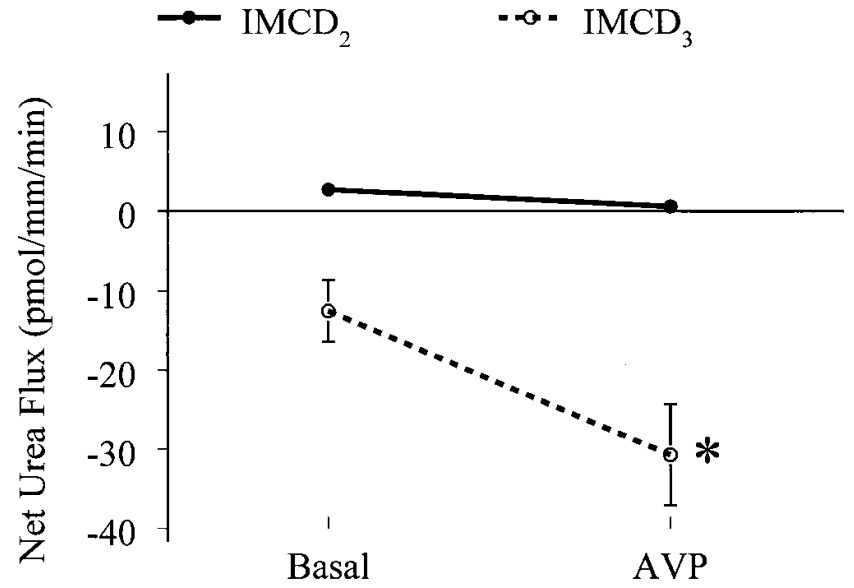

Figure 2. Effect of AVP (10 $\mathrm{nM}$ added to the bath) on net urea flux in terminal IMCD subsegments. AVP significantly increased net urea secretion in the $\mathrm{IMCD}_{3}$ but had no effect on net urea flux in the $\mathrm{IMCD}_{2}$. Data: mean \pm SE, $n=5, * P<0.01$. 
Table II. Volume Flux in IMCD $D_{3}$ with AVP $(10 \mathrm{nM})$ Added to the Bath

\begin{tabular}{lc}
\hline Tubule length & $0.6 \pm 0.1 \mathrm{~mm}$ \\
Collection rate & $18.4 \pm 2.5 \mathrm{nl} / \mathrm{min}$ \\
Perfusion rate & $18.1 \pm 2.5 \mathrm{nl} / \mathrm{min}$ \\
Collected/perfusate & \\
$\quad$ creatinine & $0.99 \pm 0.01$ \\
Volume flux & $-0.3 \pm 0.1 \mathrm{nl} / \mathrm{mm}$ per $\min (P=$ NS vs. 0$)$
\end{tabular}

Data: mean \pm SE, $n=4$.

ever, there was no significant volume flux in $\mathrm{IMCD}_{3} \mathrm{~s}$ when AVP $(10 \mathrm{nM})$ was added to the bath $(-0.3 \pm 0.1 \mathrm{nl} / \mathrm{mm}$ per min, $n=4, P=$ NS vs. 0 , Table II). In $\mathrm{IMCD}_{2} \mathrm{~s}$, AVP had no effect on net urea flux (basal: $2.7 \pm 0.8 \mathrm{pmol} / \mathrm{mm}$ per min, AVP: $0.6 \pm 0.8 \mathrm{pmol} / \mathrm{mm}$ per min, $n=5, P=\mathrm{NS}$, Fig. 2, solid line).

Effect of inhibitors on net urea flux. Phloretin $(250 \mu \mathrm{M}$ in the perfusate) inhibited net urea secretion from $-6.9 \pm 1.6$ $\mathrm{pmol} / \mathrm{mm}$ per $\min$ to $-0.5 \pm 1.0 \mathrm{pmol} / \mathrm{mm}$ per $\min (n=5, P<$ 0.01 , Fig. 3). When phloretin was removed, net urea secretion returned to $-6.1 \pm 1.3 \mathrm{pmol} / \mathrm{mm}$ per $\min (n=5, P=\mathrm{NS}$ vs. control).

Ouabain (1 $\mathrm{mM}$ in the bath) decreased net urea secretion from $-10.5 \pm 3.4 \mathrm{pmol} / \mathrm{mm}$ per min to $-2.5 \pm 1.7 \mathrm{pmol} / \mathrm{mm}$ per $\min (n=4, P<0.05$, Fig. 4$)$. When ouabain was washed out of the bath, net urea secretion returned to $-10.9 \pm 4.0 \mathrm{pmol} / \mathrm{mm}$ per $\min (n=4, P=$ NS vs. basal $)$.

Next, we examined the effect of temperature. Net urea secretion was present when $\mathrm{IMCD}_{3} \mathrm{~s}$ were warmed to $37^{\circ} \mathrm{C}$ $(-9.0 \pm 1.8 \mathrm{pmol} / \mathrm{mm}$ per min, $n=5)$ but disappeared at $23^{\circ} \mathrm{C}$ $\left(-1.3 \pm 1.6 \mathrm{pmol} / \mathrm{mm}\right.$ per min, $n=5, P<0.01$ vs. $37^{\circ} \mathrm{C}$, Fig. 5$)$.

Effect of ion substitution on net urea transport. Removing $\mathrm{Na}^{+}$from the perfusate (and replacing it with $N$-methyl-D-glucamine $^{+}$) completely inhibited net urea secretion (control: $-14.9 \pm 3.1 \mathrm{pmol} / \mathrm{mm}$ per min, $\mathrm{Na}^{+}$removal: $0.0 \pm 0.6 \mathrm{pmol} / \mathrm{mm}$ per min, $n=5, P<0.01$, Fig. 6 ). When perfusate $\mathrm{Na}^{+}$was restored, net urea secretion returned to $-8.4 \pm 2.3 \mathrm{pmol} / \mathrm{mm}$ per $\min \left(n=5, P=\mathrm{NS}\right.$ vs. control). In contrast, removing $\mathrm{Na}^{+}$ from the bath had no significant effect on net urea secretion

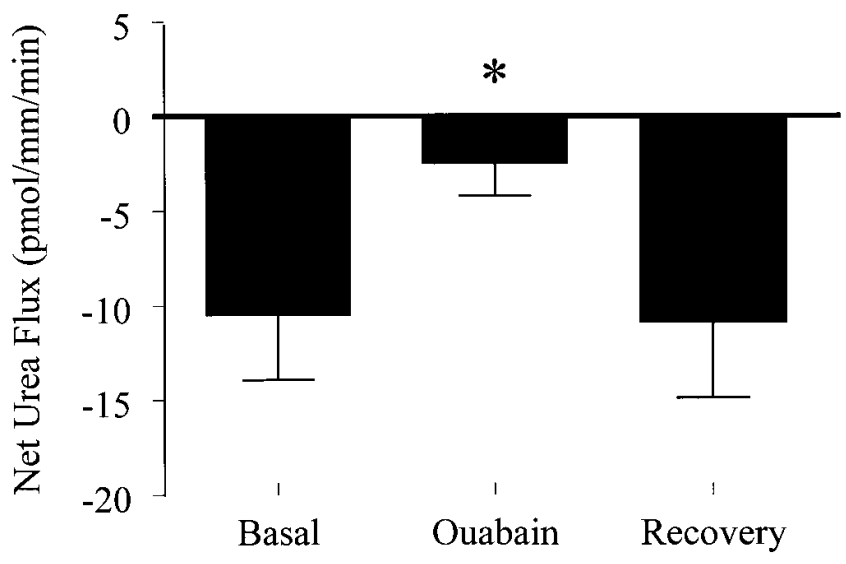

Figure 4. Effect of ouabain (1 $\mathrm{mM}$ added to the bath) on net urea secretion in the $\mathrm{IMCD}_{3}$. Ouabain significantly and reversibly inhibited net urea secretion. Data: mean $\pm \mathrm{SE}, n=4,{ }^{*} P<0.05$.

(control: $-11.9 \pm 2.0 \mathrm{pmol} / \mathrm{mm}$ per min, bath $\mathrm{Na}^{+}$removal: $-12.1 \pm 2.2 \mathrm{pmol} / \mathrm{mm}$ per min, $n=5, P=\mathrm{NS}$, Fig. 7). Removing $\mathrm{Cl}^{-}$from the perfusate (and replacing it with gluconate ${ }^{-}$) had no effect on net urea secretion (control: $-10.4 \pm 1.4 \mathrm{pmol} /$ $\mathrm{mm}$ per $\mathrm{min}, \mathrm{Cl}^{-}$removal: $-10.9 \pm 2.1 \mathrm{pmol} / \mathrm{mm}$ per $\min , n=$ 5, $P=$ NS, Fig. 8 ).

When triamterene $(100 \mathrm{nM})$ was added to the perfusate to block apical sodium channels, net urea secretion decreased from $-10.4 \pm 1.9 \mathrm{pmol} / \mathrm{mm}$ per min to $-0.6 \pm 1.0 \mathrm{pmol} / \mathrm{mm}$ per $\min (n=5, P<0.01$, Fig. 9$)$. When triamterene was removed, net urea secretion returned to $-8.1 \pm 0.5 \mathrm{pmol} / \mathrm{mm}$ per $\min (n=$ 5, $P=$ NS vs. control).

Effect of changes in hydration in vivo on net urea flux. In comparison to $\mathrm{IMCD}_{3} \mathrm{~s}$ from untreated rats $(-10.3 \pm 1.9 \mathrm{pmol} /$ mm per min, $n=15)$, $\mathrm{IMCD}_{3}$ s from rats made water diuretic (but not given any food) for 3-5 d had significantly higher net urea secretion $(-21.9 \pm 4.7 \mathrm{pmol} / \mathrm{mm}$ per $\min , n=6, P<0.01$ vs. untreated rats, Fig. 10). $\mathrm{IMCD}_{3}$ s from rats made water diuretic for 3-5 d and given food ad libitum had even higher net urea secretion $(-50.2 \pm 8.3 \mathrm{pmol} / \mathrm{mm}$ per $\min , n=5, P<0.01$ vs. untreated rats or water diuretic rats which were not given

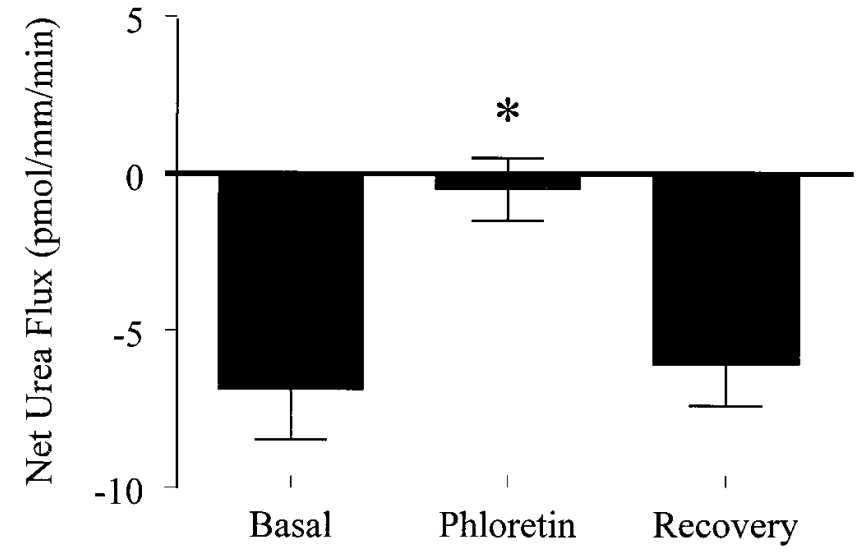

Figure 3. Effect of phloretin ( $0.25 \mathrm{mM}$ added to the perfusate) on net urea secretion in the $\mathrm{IMCD}_{3}$. Phloretin significantly and reversibly inhibited net urea secretion. Data: mean \pm SE, $n=5, * P<0.01$.

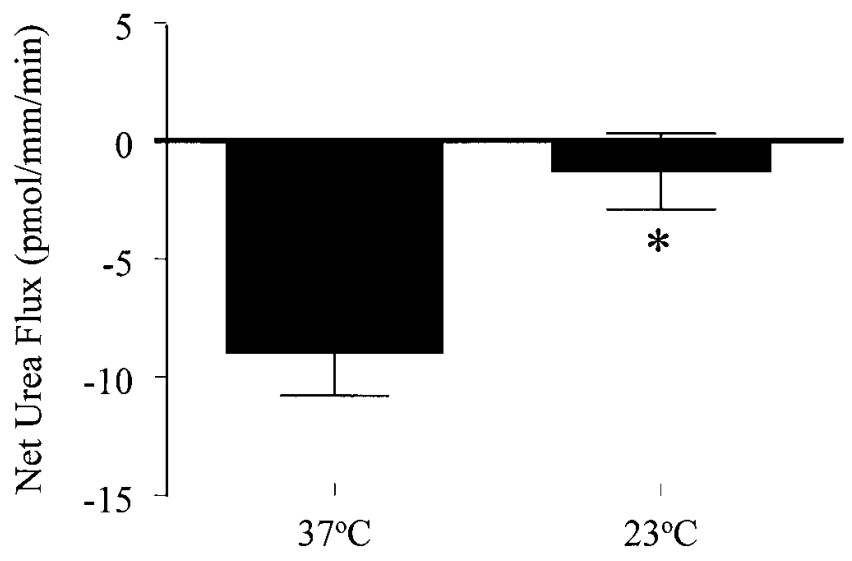

Figure 5. Effect of temperature on net urea secretion in the $\mathrm{IMCD}_{3}$. Cooling the tubule to room temperature significantly inhibited net urea secretion. Data: mean \pm SE, $n=6, * P<0.01$. 


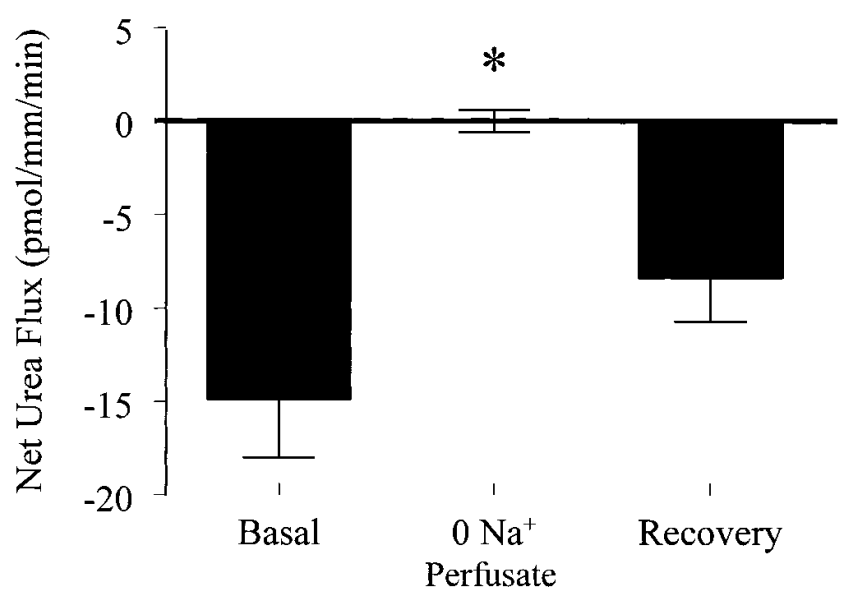

Figure 6. Effect of $\mathrm{Na}^{+}$removal from the perfusate on net urea secretion in the $\mathrm{IMCD}_{3}$. Removing $\mathrm{Na}^{+}$from the perfusate (and replacing it with $N$-methyl-D-glucamine ${ }^{+}$) significantly and reversibly inhibited net urea secretion. Data: mean $\pm \mathrm{SE}, n=5, * P<0.01$.

food). $\mathrm{IMCD}_{3}$ s from rats which were water restricted for $2-3 \mathrm{~d}$ but were given food ad libitum had net urea secretion $(-7.4 \pm 2.1 \mathrm{pmol} / \mathrm{mm}$ per $\min , n=7)$ which was not significantly different from that in untreated rats.

\section{Discussion}

Our major finding is the identification of a previously unrecognized, secondary active, sodium-coupled, urea secretory transport mechanism in the rat $\mathrm{IMCD}_{3}$ subsegment. Urea flux via this pathway is upregulated in water-diuretic rats. This ureasecretory transport mechanism was completely and reversibly inhibited by removing luminal sodium but not by removing luminal chloride or bath sodium. Blockade of apical sodium channels by luminal triamterene (18) also inhibited net urea secretion. Inhibition of net urea secretion by ouabain or by cooling the tubule to $23^{\circ} \mathrm{C}$ further suggest that this urea trans-

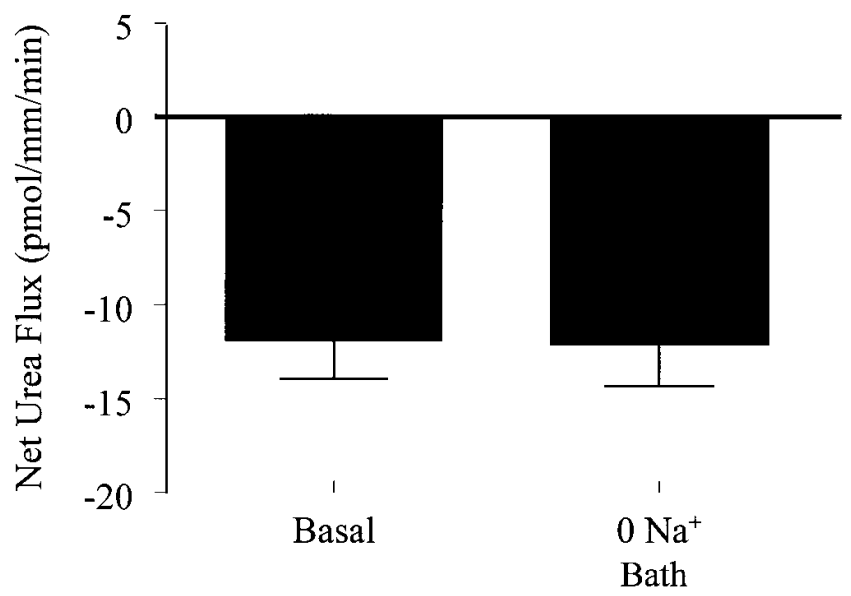

Figure 7. Effect of $\mathrm{Na}^{+}$removal from the bath on net urea secretion in the $\mathrm{IMCD}_{3}$. Bath $\mathrm{Na}^{+}$removal did not change net urea secretion. Data: mean \pm SE, $n=5$.

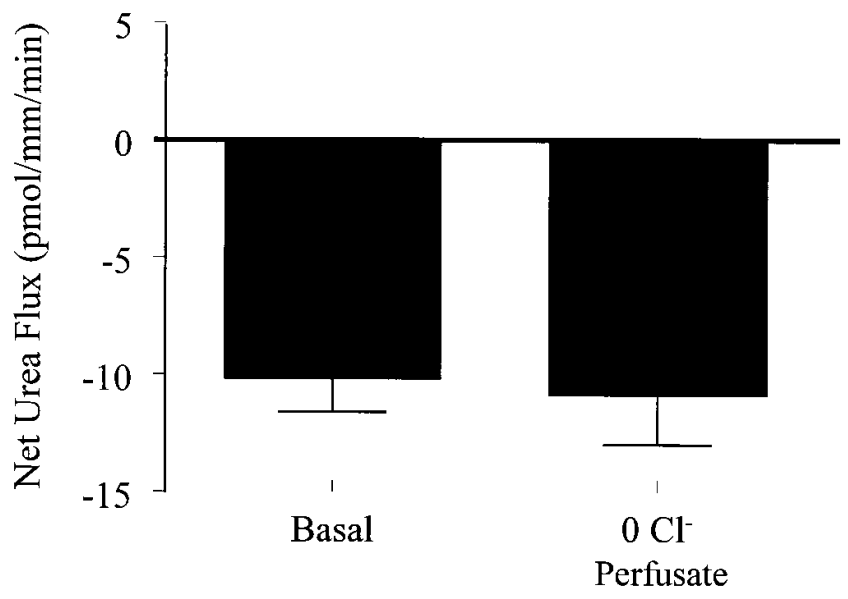

Figure 8. Effect of $\mathrm{Cl}^{-}$removal from the perfusate on net urea secretion in the $\mathrm{IMCD}_{3}$. Perfusate $\mathrm{Cl}^{-}$removal did not change net urea secretion. Data: mean \pm SE, $n=5$.

port process is an $\mathrm{Na}^{+} / \mathrm{K}^{+}$-ATPase dependent, secondary active process.

Comparison to other active urea transport processes. There are previous studies suggesting the existence of active urea transport. There are phloretin-inhibitable and/or sodium-independent active urea transport processes in Bufo bufo (23), Bufo viridis $(24,25)$, Rena esculenta (26), and Bufo marinus (27). The active urea transport processes in the skin of Bufo viridis (25) and Bufo marinus (27) are also inhibited by amiloride. Like amiloride, triamterene also inhibits the amiloridesensitive sodium channel (18). We used triamterene because we found that amiloride interfered with our fluorometric urea assay (unpublished observation).

Active urea secretion has been reported in the kidney of frog $(3,4)$, rabbit $(5), \operatorname{dog}(7,8)$, and human (9). In the kidney, Schmidt-Nielsen and colleagues demonstrated active urea transport which is coupled to sodium reabsorption in the spiny dogfish, Squalus acanthias (2). In rats, we found that sodiumdependent active urea reabsorption appears in the initial IMCD when rats are fed a low-protein diet (11-13). However,

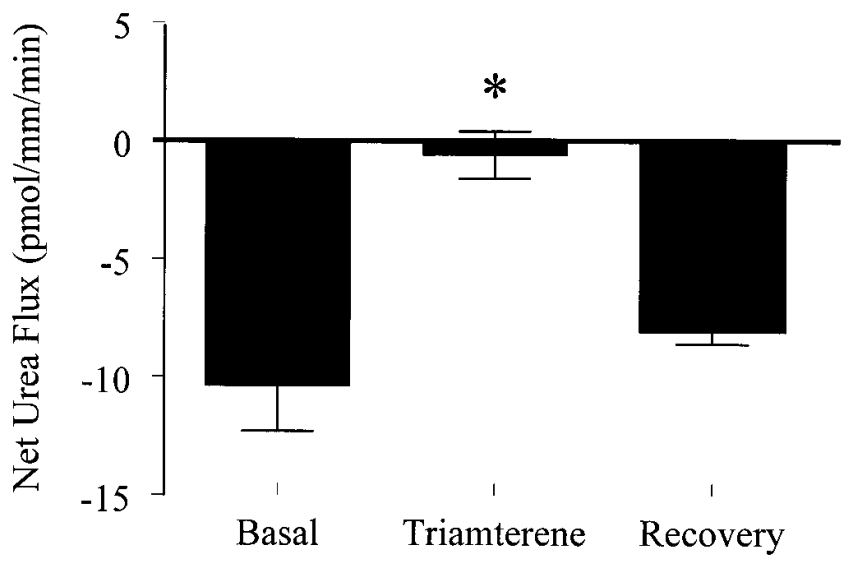

Figure 9. Effect of triamterene ( $100 \mathrm{nM}$ added to the perfusate) on net urea secretion in the $\mathrm{IMCD}_{3}$. Triamterene significantly and reversibly inhibited net urea secretion. Data: mean $\pm \mathrm{SE}, n=5,{ }^{*} P<$ 0.01 . 


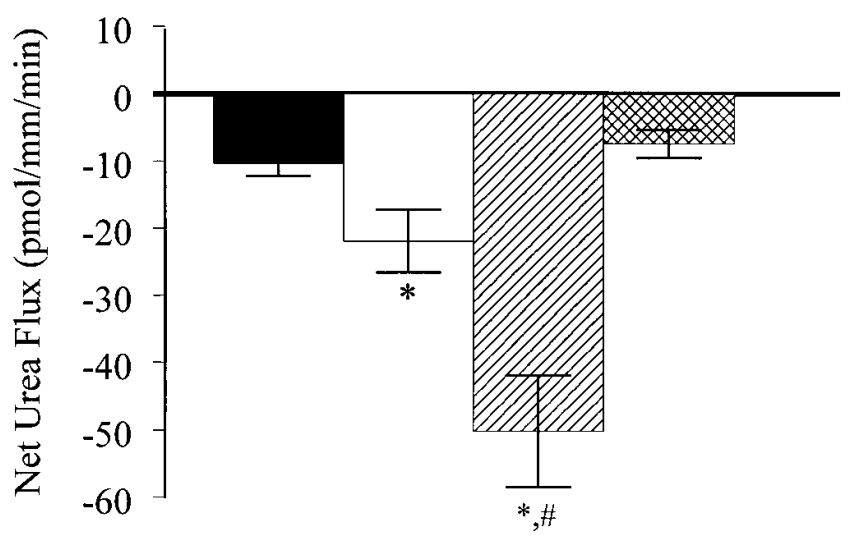

Figure 10. Effect of changes in hydration status in vivo. Compared to $\mathrm{IMCD}_{3}$ s from untreated rats (solid bar, $n=15$ ), $\mathrm{IMCD}_{3}$ s from rats made water diuretic but not given food for 3-5 $\mathrm{d}$ had significantly higher net urea secretion (open bar, $n=6$ ). $\mathrm{IMCD}_{3}$ s from rats made water diuretic and given food ad libitum for 3-5 $\mathrm{d}$ had even higher net urea secretion (striped bar, $n=5$ ). $\mathrm{IMCD}_{3}$ s from rats which were water restricted but given food for 2-3 d had net urea secretion which was not significantly different from that found in untreated rats (cross-hatched bar, $n=7$ ). Data: mean $\pm \mathrm{SE}, * P<0.01$ vs. untreated rats, $\# P<0.01$ vs. water-diuretic rats which were not given food.

the net urea flux we found in the present study has characteristics distinct from net urea reabsorption expressed in response to dietary protein restriction. First, the active urea-secretory transport process we identified in the present study is inhibited by phloretin and stimulated by AVP, while the active urea reabsorptive transport appearing in response to a low-protein diet is not affected by phloretin or AVP $(11,13)$. Second, active urea-secretory transport is expressed in $\mathrm{IMCD}_{3} \mathrm{~s}$, but not in $\mathrm{IMCD}_{1} \mathrm{~s}$ or $\mathrm{IMCD}_{2} \mathrm{~s}$, from rats eating a normal protein diet, while active urea-reabsorptive transport was only expressed in $\mathrm{IMCD}_{1} \mathrm{~s}$ after $3 \mathrm{wk}$ of feeding rats a low-protein diet (12). Thus, the present study is the first demonstration in a mammalian-collecting duct subsegment, the $\mathrm{IMCD}_{3}$, of a sodium-dependent, phloretin-inhibitable, triamterene-inhibitable, AVP-stimulatable, secondary active, urea-secretory transport mechanism.

Physiologic role of net urea secretion in the $\mathrm{IMCD}_{3}$ subsegment. A high rate of net urea secretion in the $\mathrm{IMCD}_{3}$ would be expected to reduce urea accumulation in the papillary tip. Counteracting this effect, there is facilitated urea reabsorption mediated by the AVP-regulated urea transporter UT-A1 (UT-1) $(16,28-31)$. We calculated the quantitative effect of net urea secretion and facilitated urea reabsorption based on the following estimates: (a) facilitated urea reabsorption in $\mathrm{IMCD}_{3} \mathrm{~S}$ was $125 \mathrm{pmol} / \mathrm{mm}$ per min when we imposed a $5 \mathrm{mM}$ bathto-lumen urea gradient (32); and (b) the urea concentration difference between papillary interstitial fluid and urine is $243 \pm 50 \mathrm{mM}$ in normal rats (33). Consequently, the calculated urea reabsorptive flux mediated by facilitated urea transport is $\sim 6,000 \mathrm{pmol} / \mathrm{mm}$ per min, a value $\sim 500$ times higher than the net urea-secretory flux we measured in the present study. Thus, net urea secretion may play a minor role in overall urea transport in $\mathrm{IMCD}_{3} \mathrm{~s}$ from normal rats.

Any urea gradient created by urea secretion into the $\mathrm{IMCD}_{3}$ lumen could result in a "backleak" of urea because the $\mathrm{IMCD}_{3}$ also expresses facilitated urea transport (16). Thus, the rate of net urea secretion which we measured may underestimate the actual rate of urea secretion. Using the values in Table I, a tubule inner diameter of $30 \mu \mathrm{m}$, and a basal urea permeability of $50 \times 10^{-5} \mathrm{~cm} / \mathrm{s}(15,32)$, the calculated maximal rate of urea "backleak" would be $4 \mathrm{pmol} / \mathrm{mm}$ per min. Adding this value to the measured value for net urea secretion would suggest an actual urea secretory rate of $15 \mathrm{pmol} / \mathrm{mm}$ per min in $\mathrm{IMCD}_{3} \mathrm{~s}$ from untreated rats. This value is also far below the reabsorption value, so under normal conditions, urea is reabsorbed across the $\mathrm{IMCD}_{3}$.

Water diuresis, however, increases the fractional excretion of urea (34). This implies net movement of urea from the medullary interstitium into the $\mathrm{IMCD}_{3}$ lumen. Results from tissue slice data are consistent with this formulation $(35,36)$. Moreover, Wilson and Sonnenberg (37) showed that either water or mannitol-induced diuresis increases urea secretion from the distal portion of the rat medullary collecting duct using their microcatheterization technique. We found that net urea secretion was upregulated twofold in $\mathrm{IMCD}_{3}$ s from rats undergoing water diuresis but food restricted, and upregulated fivefold in rats undergoing water diuresis and allowed to eat ad libitum. Thus, an increase in urea secretion into the $\mathrm{IMCD}_{3}$ lumen may contribute to the higher fractional excretion of urea during water diuresis.

Another consideration is the influence of this transport process on sodium flux. In the IMCD, sodium reabsorption occurs predominantly via amiloride-sensitive sodium channels in the apical membrane and $\mathrm{Na}^{+} / \mathrm{K}^{+}$-ATPase in the basolateral membrane (38). Since we found that net urea secretion was inhibited by both triamterene (in the lumen) and ouabain (in the bath), we concluded that net urea secretion is coupled to sodium reabsorption in $\mathrm{IMCD}_{3}$ s. Water diuresis is known to increase sodium delivery and reabsorption in the rat medullary collecting duct $(39,40)$. Thus, it is possible that upregulation of this sodium-dependent, net urea secretory transport mechanism is a response to water diuresis and mediates the increase in net urea secretion and sodium reabsorption which occurs in vivo.

It is interesting to consider why there are two urea transport pathways. Water deprivation decreases the fractional excretion of urea (34) but it had no effect upon net urea secretion. On the other hand, we found upregulation of facilitated urea transport in $\mathrm{IMCD}_{3} \mathrm{~s}$ by 2-3 d of water deprivation (32). Thus, during antidiuresis, the latter pathway rather than active urea secretion probably plays the major role in determining urea accumulation in the inner medulla.

The influence of AVP on urea transport is more difficult to understand. The acute increase in urea secretion after adding AVP (Fig. 2) could be linked to stimulation of sodium reabsorption by the hormone (41-43). Prolonged water deprivation should have increased plasma AVP levels yet there was no stimulation of urea secretion (Fig. 10). We cannot explain this difference but Atherton and colleagues (44) showed that maintenance of a high plasma AVP level for several hours reduces the rate of sodium excretion to pre-AVP levels. These data suggest that there are differences between acute and longterm effects of AVP and suggest the possibility that decreased sodium reabsorption during long-term antidiuresis could limit net urea secretion in $\mathrm{IMCD}_{3} \mathrm{~s}$ from water-restricted rats.

Cloned urea transporters. Recently, several facilitated urea transporters have been cloned and shown to exist within mam- 
malian nephron segments (see reference 31 for a review). An active urea transporter, DUR3, has been cloned from Saccharomyces cerevisiae (45). However, urea transport by DUR3 is independent of sodium (45). Initial expression cloning using Xenopus laevis oocytes showed that the reabsorptive active urea transport induced by a low-protein diet is encoded by a 4.4-8.4 kb mRNA size fraction from rat inner medulla (46). Additional studies are needed to examine active urea transport at the molecular level.

Summary. We found that urea is actively secreted in the deepest portion of the IMCD, the $\mathrm{IMCD}_{3}$ of normal rats. This net urea secretion is dependent upon luminal sodium, inhibited by phloretin and triamterene, and upregulated by water diuresis. Inhibition of $\mathrm{Na}^{+} / \mathrm{K}^{+}$-ATPase also reduced net urea secretion. We propose that net urea secretion in the rat $\mathrm{IMCD}_{3}$ occurs via a previously unrecognized, secondary active, sodium-urea antiporter.

\section{Acknowledgments}

The authors thank Dr. William E. Mitch (Emory University, Atlanta, GA) for his critical reading of this manuscript.

This work was supported by Grant-in-Aid 96006090 from the American Heart Association and National Institutes of Health grants R01-DK41707 and P01-DK50268.

\section{References}

1. Schmidt-Nielsen, B., and L. Rabinowitz. 1964. Methylurea and acetamide; active reabsorption by elasmobranch renal tubules. Science. 146:15871588 .

2. Schmidt-Nielsen, B., B. Truniger, and L. Rabinowitz. 1972. Sodiumlinked urea transport by the renal tubule of the spiny dogfish Squalus acanthias. Comp. Biochem. Physiol. A Comp. Physiol. 42A:13-25.

3. Forster, R.P. 1954. Active cellular transport of urea by frog renal tubules. Am. J. Physiol. 179:372-377.

4. Schmidt-Nielsen, B., and C.R. Shrauger. 1963. Handling of urea and related compounds by the renal tubules of the frog. Am. J. Physiol. 205:483-488.

5. Kawamura, S., and J.P. Kokko. 1976. Urea secretion by the straight segment of the proximal tubule. J. Clin. Invest. 58:604-612.

6. Knepper, M.A. 1983. Urea transport in nephron segments from medullary rays of rabbits. Am. J. Physiol. 244:F622-F627.

7. Beyer, K.H., Jr., and R.T. Gelarden. 1988. Active transport of urea by mammalian kidney. Proc. Natl. Acad. Sci. USA 85:4030-4031.

8. Beyer, K.H., Jr., R.T. Gelarden, and E.S. Vesell. 1992. Inhibition of urea transport across renal tubules by pyrazinonylguanidine and analogs. Pharmacology. 44:124-138.

9. Beyer, K.H., Jr., R.T. Gelarden, J.E. Vary, L.E. Brown, and E.S. Vesell. 1990. Novel multivalent effects of pyrazinonylguanidine in patients with azotemia. Clin. Pharmacol. Ther. 47:629-638.

10. Madsen, K.M., W.L. Clapp, and J.W. Verlander. 1988. Structure and function of the inner medullary collecting duct. Kidney Int. 34:441-454.

11. Isozaki, T., J.W. Verlander, and J.M. Sands. 1993. Low protein diet alters urea transport and cell structure in rat initial inner medullary collecting duct. J. Clin. Invest. 92:2448-2457.

12. Isozaki, T., A.G. Gillin, C.E. Swanson, and J.M. Sands. 1994. Protein restriction sequentially induces new urea transport processes in rat initial IMCDs. Am. J. Physiol. 266:F756-F761.

13. Isozaki, T. J.P. Lea, J.A. Tumlin, and J.M. Sands. 1994. Sodium-dependent net urea transport in rat initial IMCDs. J. Clin. Invest. 94:1513-1517.

14. Clapp, W.L., K.M. Madsen, J.W. Verlander, and C.C. Tisher. 1989. Morphologic heterogeneity along the rat inner medullary collecting duct. Lab. Invest. 60:219-230.

15. Sands, J.M., and M.A. Knepper. 1987. Urea permeability of mammalian inner medullary collecting duct system and papillary surface epithelium. J. Clin. Invest. 79:138-147.

16. Sands, J.M., H. Nonoguchi, and M.A. Knepper. 1987. Vasopressin effects on urea and $\mathrm{H}_{2} \mathrm{O}$ transport in inner medullary collecting duct subsegments. Am. J. Physiol. 253:F823-F832.

17. Terada, Y., and M.A. Knepper. 1989. $\mathrm{Na}^{+}-\mathrm{K}^{+}$-ATPase activities in renal tubule segments of rat inner medulla. Am. J. Physiol. 256:F218-F223.

18. Schlanger, L.E., T.R. Kleyman, and B.N. Ling. 1994. $\mathrm{K}^{+}$-sparing diuretic actions of trimethoprim: inhibition of $\mathrm{Na}^{+}$channels in $\mathrm{A} 6$ distal nephron cells. Kidney Int. 45:1070-1076.

19. Chou, C.-L., and M.A. Knepper. 1989. Inhibition of urea transport in inner medullary collecting duct by phloretin and urea analogues. Am. J. Physiol. 257:F359-F365.

20. Gillin, A.G., and J.M. Sands. 1992. Characteristics of osmolarity-stimulated urea transport in the rat IMCD. Am. J. Physiol. 262:F1061-F1067.

21. Sands, J.M., M.A. Knepper, and K.R. Spring. 1986. Na-K-Cl cotransport in apical membrane of rabbit renal papillary surface epithelium. Am. J. Physiol. 251:F475-F484.

22. Snedecor, G.W., and W.G. Cochran. 1980. Statistical Methods. Iowa State University Press, Ames, IA. 217-236.

23. Ussing, H., and B. Johnansen. 1969. Anomolous transport of sucrose and urea in toad skin. Nephron. 6:317-328.

24. Katz, U., F. Garcia-Romeu, A. Masoni, and J. Isaia. 1981. Active transport of urea across the skin of the euryhaline toad, Bufo viridis. Pfluegers Arch. 390:299-300.

25. Rapoport, J., A. Abuful, C. Chaimovitz, Z. Noeh, and R.M. Hays. 1988. Active urea transport by the skin of Bufo viridis: amiloride- and phloretin-sensitive transport sites. Am. J. Physiol. 255:F429-F433.

26. Lacoste, I., S. Dunel-Erb, B.J. Harvey, P. Laurent, and J. Ehrenfeld. 1991. Active urea transport independent of $\mathrm{H}^{+}$and $\mathrm{Na}^{+}$transport in frog skin epithelium. Am. J. Physiol. 261:R898-R906.

27. Dytko, G., P.L. Smith, and L.B. Kinter. 1993. Urea transport in toad skin (Bufo marinus). J. Pharmacol. Exp. Ther. 267:364-370.

28. Shayakul, C., A. Steel, and M.A. Hediger. 1996. Molecular cloning and characterization of the vasopressin-regulated urea transporter of rat kidney collecting ducts. J. Clin. Invest. 98:2580-2587.

29. Shayakul, C., M.A. Knepper, C.P. Smith, S.R. DiGiovanni, and M.A Hediger. 1997. Segmental localization of urea transporter mRNAs in rat kidney. Am. J. Physiol. 272:F654-F660.

30. Nielsen, S., J. Terris, C.P. Smith, M.A. Hediger, C.A. Ecelbarger, and M.A. Knepper. 1996. Cellular and subcellular localization of the vasopressinregulated urea transporter in rat kidney. Proc. Natl. Acad. Sci. USA. 93:54955500.

31. Sands, J.M., R.T. Timmer, and R.B. Gunn. 1997. Urea transporters in kidney and erythrocytes. Am. J. Physiol. 273:F321-F339.

32. Kato, A., M. Naruse, M.A. Knepper, and J.M. Sands. 1998. Long-term regulation of inner medullary collecting duct urea transport in rat. J. Am. Soc. Nephrol. In press.

33. Bulger, R.E. 1987. Composition of renal medullary tissue. Kidney Int. 31:556-561.

34. Bankir, L. 1996. Urea and the kidney. In The Kidney, 5th edition, B.M Brenner, editor. W.B. Saunders Co., Philadelphia, 571-606.

35. Atherton, J.C., M.A. Hai, and S. Thomas. 1968. The time course of changes in renal tissue composition during water diuresis in the rat. J. Physiol. 197:429-443.

36. Yancey, P.H., and M.B. Burg. 1989. Distribution of major organic osmolytes in rabbit kidneys in diuresis and antidiuresis. Am. J. Physiol. 257:F602F607.

37. Wilson, D.R., and H. Sonnenberg. 1981. Urea secretion in medullary collecting duct of the rat kidney during water and mannitol diuresis. Am. J. Physiol. 240:F165-F171.

38. Zeidel, M.L. 1993. Hormonal regulation of inner medullary collecting duct sodium transport. Am. J. Physiol. 265:F159-F173.

39. Sonnenberg, H. 1974. Medullary collecting-duct function in antidiuretic and in salt- or water-diuretic rats. Am. J. Physiol. 226:501-506.

40. Cupples, W.A., and H. Sonnenberg. 1987. Load dependency of sodium chloride reabsorption by medullary collecting duct in rat. Am. J. Physiol. 253 F642-F648.

41. Ullrich, K.J., and F. Papavassiliou. 1979. Sodium reabsorption in the papillary collecting ducts of rats. Pfluegers Arch. 379:49-52.

42. Kudo, L.H., A.A. Van Baak, and A.S. Rocha. 1990. Effect of vasopressin on sodium transport across inner medullary collecting duct. Am. J. Physiol. 258:F1438-F1447.

43. Sands, J.M., H. Nonoguchi, and M.A. Knepper. 1988. Hormone effects on $\mathrm{NaCl}$ permeability of rat inner medullary collecting duct subsegments. Am. J. Physiol. 255:F421-F428.

44. Atherton, J.C., R. Green, and S. Thomas. 1971. Influence of lysine-vasopressin dosage on the time course of changes in renal tissue and urinary composition in the conscious rat. J. Physiol. 213:291-309.

45. El Berry, H.M., M.L. Majumdar, T.S. Cunningham, R.A. Sumrada, and T.G. Cooper. 1993. Regulation of the urea active transporter gene (DUR3) in Saccharomyces cerevisiae. J. Bacteriol. 175:4688-4698.

46. Sands, J.M., S. Martial, and T. Isozaki. 1996. Active urea transport in the rat initial inner medullary collecting duct: functional characterization and initial expression cloning. Kidney Int. 49:1611-1614 